\title{
Yetiştirme Yurdunda Kalan Ergenlerin Sorunları ve Başetmeleri
}

\author{
Adolescence in Orphanages Problems and Coping Methods
}

\author{
Elif AŞIK ${ }^{1}$, Fatma EKER ${ }^{2}$ \\ ${ }^{1}$ Kırıkkale Üniversitesi Sağlık Bilimleri Fakültesi Hemşirelik Bölümü, KIRIKKALE \\ ${ }^{2}$ Düzce Üniversitesi Să̆lık Yüksekokulu, DÜZCE
}

\begin{abstract}
ÖZET
Gençler ergenlik dönemine özgü çeşitli sorunlar yaşamaktadırlar. Yetiştirme yurdunda kalan gençlerde ergenlik sorunları daha fazla görülmektedir. Bu nedenle yetiştirme yurdundaki ergenlerin baş etmeleri önemlidir.

$\mathrm{Bu}$ çalışma, yetiştirme yurtlarında kalan ergenlerin sorunlarını ve baş etme yöntemlerini belirlemek amacıyla tanımlayıcı tipte yapılmıştır. Araştırmanın örneklemi yetiştirme yurtlarında kalan 12-19 yaşlarında 87 ergenden oluşmuştur. Araştırmanın verileri, araştırmacı tarafından geliştirilen Öğrenci Bilgi Formu, Ergen Problem Tarama Listesi ve Ergenlerde Sorunlarla Başa Çıkma Ölçeği aracılığıyla, gözlem altında anketlerin uygulanmasıyla toplanmıştır.
\end{abstract}

Araştırmadan elde edilen veriler bir istatistik programında değerlendirilmiştir. Verilerin analizinde yüzdelik, ortalama, standart sapma, t testi, tek yönlü varyans analizi (ANOVA), Kruskal-Wallis testi, Scheffe testi, Mann-Whitney U testi ve korelasyon katsayısı kullanılmıştır.

Araştırmaya katılan ergenlerin \% 51,7'sinin erkek, \% 69,0'unun 15-17 yaş grubunda olduğu tespit edildi. Erkeklerde karşı cinsle arkadaşlık ve cinsel problemleri öğrenme daha fazla bulundu. Sorunlarla baş etmede madde kullanma yöntemi; erkeklerde, okula devam etmeyenlerde, ana-babasının her ikisi de ölmüş olanlarda, sigara içenlerde, olumsuz duyguları dışa vurma ise; erkeklerde daha fazla kullanıldığı belirlendi. Gruplar arasındaki fark istatistiksel olarak anlamlı bulundu $(\mathrm{p}<0,05)$.

Araştırmadan elde edilen sonuçlara göre, yetiştirme yurdunda yaşayan ergenlerde en fazla güçlük yaşanan alan gelecekle ilgili düşünce ve istekler alanıdır ve en çok kullanılan baş etme yöntemleri kendini geliştirme, duygusal rahatlama ve sorunu ciddiye almama/şaka yapmadır. Sonuçlar doğrultusunda, yetiştirme yurdunda kalan ergenlerin düzenli izlenmeleri, sorunlarının çözümünde danışmanlık verilmesi ve bahşetmelerinin güçlendirilmesi önerilmiştir.

Anahtar Kelimeler: Ergenlik, Yetiştirme Yurtları, Başetme davranışları
Adolescents have some specific adolescence problems. Adolescents who live in orphanages have more problems than the others. So that coping methods of adolescents who live in orphanages are important.

This descriptive study was done to determine the adolescence problems and coping methods of adolescents who live in orphanages. The sample of the study composed of 87 adolescent boys and girls between 12-19 ages which are under the authority of Social Services and Child Protection Association. The data of the study was collected by Student Information Form which was developed by the researcher, Adolescence Problems Scanning List and The Scale Of Coping with the problems in adolescence. The questionnaires were filled in under researcher's observation. The data obtained from the study was assessed in a statistical program. Percentage, mean, standard deviation, $t$ test, one way ANOVA, Kruskal-Wallis, Scheffe test, Mann-Whitney U test and correlation were used to analyze the data.

It is identified that most of the adolescents who participated this study are boys (\%51.7), between 15-17 ages (\%69.0) and group of medium adolescence. Making friends with the opposite gender and learning sexual problems are more seen in boys. Using drugs as a coping method is more seen in these groups: boys, the ones who don't attend school, who lost their parents, who smokes, boys show their negative feelings more than girls. The difference between groups is statistically significant $(\mathrm{p}<0.05)$.

According to the results of the study the most problematic field has been experienced by the orphanage adolescents is thoughts and demands about future and the most used methods are self-developing, emotional relaxation and not to take the problem serious/making jokes. With direction of our results, were suggest, that adolescence in orphanage should be observed regularly, they should be given consultants for solving their problems and they should be strengthened for coping behaviors.

Keywords: Adolescence, Orphanages, Coping methods

* Eylül 2007 de Ankara'da düzenlenen IV. Uluslararası XI. Ulusal Hemşirelik Kongresinde poster bildirisi olarak sunulmuştur.

KÜ T1p Fak Derg 2014; 16(2): 20-31

Geliş Tarihi / Received: 10.02 .2014

Kabul Tarihi / Accepted: 22.04.2014
Yazışma Adresi / Correspondence: Elif ÂŞIK

KÜ Sağlık Bilimleri Fakültesi, Hemşirelik Bölümü, KIRIKKALE

E-mail: elifasik@kku.edu.tr Tel: 05053846721 


\section{GíRìş}

İnsan yaşamı, doğumdan ölüme sınırları çok kesin olmayan dönemlere ayrilır. $\mathrm{Bu}$ dönemlerin her birinin kendine özgü özellikleri vardır ve kendinden önceki dönemden etkilendiği gibi kendinden sonraki dönemi de etkiler. Yaşamın önemli dönemlerinden biri olan ergenlik, çocukluk ve yetişkinlik arasında yer alan, gelişme, ruhsal olgunlaşma ve yaşama hazırlık dönemidir. Ergenlik dönemi büyümenin durmasına kadar sürer ve 12-21 yaşlarını kapsar. Dünya Sağlık Örgütü 10-19 yaşları arasını ergenlik dönemi olarak kabul etmektedir (1). Her ne kadar ergenlik dönemi için bazı yaş sınırları çizilse de bu dönemi kesin bir yaş grubu olarak ayırmak oldukça zordur.

Dünya nüfusunun neredeyse yarısı 25 yaşın altındaki bireylerden oluşmaktadır. UNFPA 2005 yılı raporunda dünya nüfusunun 1,2 milyarının, 10-19 yaşları arasındaki ergenlerden oluştuğu bildirilmektedir (2). Ülkemizde ise 2000 genel nüfus sayımı itibariyle 10-19 yaşları arası nüfus 14 milyondur (3). Bu veriler değerlendirildiğinde, gençlerin nüfusun büyük bir kısmını oluşturduğu görülmektedir.

Gelişimin en önemli dönemlerinden olan ergenlik dönemi; ergenin hızla oluşan biyolojik ve psikolojik değişmelere sağlıklı uyum yapmakta zorlandığı, çocukluk döneminin sona ermesiyle gerçek yaşam beklentileri ile başetme çabasına giriştiği bir kimlik arayışı dönemidir $(4,5)$. Ergenlikle başlayan hızlı büyüme bu dönem sonunda bedensel, cinsel ve ruhsal olgunlukla biter (6-10).

Ergenlik dönemine özgü duygu düşünce, tutum, davranış içinde ergenler duygusal coşku ve taşkınlık, çabuk kırılma ve ilişkilerde bozulma, kolay etkilenme, toplum içinde sivrilme, aile, okul, öğretmen gibi otoritelere karşı gelme, kurallara uymak istememe, ilgi çekme ve rol sahibi olma biçiminde davranışlar sergileyebilmektedir. $\mathrm{Bu}$ davranışlar sonucunda, akademik başarı düşmekte ve sigara ve alkol gibi madde kullanımı başlamaktadır (10-12).
Ergenlerin, ergenlik dönemine özgü, bedensel, toplumsal, ruhsal gelişim, karşı cinsle ilişki ve gelecek ile ilgili sorunları vardır. Ailesinden uzakta, onların desteğini almaksızın yetiştirme yurdunda yaşayan, ergenlerde içinde bulundukları dönemin getirdiği bu sorunlar katlanarak artmaktadır. Ülkemizde halen Sosyal Hizmetler ve Çocuk Esirgeme Kurumu (SHÇEK)'na bağlı 109 yetiştirme yurdunda toplam 10042 korunmaya muhtaç ergen bulunmaktadır (13). İçinde bulundukları dönemin özellikleri nedeniyle bağımsız olma çabasındaki ergenler, aynı zamanda kendilerine rol modeli olacak, onları koruyup tehlikelerden koruyacak büyüklerin desteğine gereksinim duyarlar. Ancak kışla tipi bakım veren yetiştirme yurtlarında aile ortamının özellikleri her zaman sağlanamaya bilmektedir (6).

İster ailesiyle birlikte isterse yetiştirme yurdunda yaşasın, ergenlerden bulundukları dönemin fizyolojik değişimleriyle başetmeleri, artan bilişsel kapasiteyi yaşam deneyimleriyle bütünleştirmeleri, bağımsızlaşmaları, aynı veya karşı cinsten yaşıtlarıyla uygun sosyal ilişkileri sağlamaları, akademik başarı beklentilerini karşılamaları, meslek seçmeleri ve yetişkin rollerine rehberlik edecek değerleri geliştirmeleri beklenir. Sorunlarla başetme davranışı, ergenin yaşamının bu evresindeki gelişim görevlerini dengeleme ve başarması için kullandığı psikososyal becerilerin önemli bileşenlerinden biri olarak kabul edilmektedir (7,9-12).

Başetme ergenin yaşamın bu döneminde ortaya çıkan ve birbiriyle çatışan biyolojik, duygusal ve sosyal taleplere uyum sağlama aracıdır. Ergenlikte başetme sadece ne yapacağını bilmeyi değil aynı zamanda belirsizlik, kestirilemezlik ve stres öğelerini içeren durumlarla karşılaşıldığında bilişsel, sosyal ve davranışsal becerilerin esnek bir şekilde yönetilmesini içermektedir $(14,15)$. Yetiştirme yurtlarındaki hemşireler, ergenlerin ergenlik dönemine özgü sorunlarını ve başetme yöntemlerini yakından izleyebilecek, etkin başetme yöntemlerini 
kullanmıyorlarsa bunları etkin olanlarla değiştirmeleri için eğitim ve danışmanlık sunabilecek konumdaki profesyonel sağlık meslek mensubudur. Yapılan çalışmaların sonuçlarına göre, yetiştirme yurtlarında kalan gençlerin yakından izlenilmesi gereken risk gruplarından olduğu bildirilmektedir (11,16-29).

Yetiştirme yurdundaki ergenlerin yaşadıkları sorunlar kullandıkları başetme yöntemleri ve problemler ile başetme arasındaki ilişkiyi incelemek amacı ile bu çalışma tanımlayıcı tipte yapıldı.

\section{GEREÇ (HASTALAR) VE YÖNTEM}

Araştırmanın evrenini Bolu il merkezindeki, İzzet Baysal Vakfı Huzurevi ve Kız Yetiştirme Yurdu'nda kalan 12-19 yaş grubunda olan 46 kız ergen ve Düzce Erkek Yetiştirme Yurdunda kalan aynı yaş grubundaki 58 erkek toplam 104 ergen oluşturdu. Bolu İzzet Baysal Vakfı Huzurevi ve Kız Yetiştirme Yurdu'nda kalan dört ergen, Düzce Erkek Yetiştirme Yurdunda kalan bir ergen zihinsel engeli nedeniyle araştırma kapsamına alınmadı. Araştırmanın verilerinin toplandığı tarihlerde yurtta bulunmayan (izinli, kaçak vb. olan) 12 ergen araştırmaya dâhil edilmedi ve 87 ergene $(\% 84)$ ait verilerin toplanmasıyla araştırma tamamland.

Araştırmanın verileri, araştırmacı tarafından geliştirilen Öğrenci Bilgi Formu, Ergen Problem Tarama Listesi ve Ergenlerde Sorunlarla Başa Çıkma Ölçeği aracılığıyla, gözlem altında anketlerin uygulanmasıyla topland1. Öğrenci Bilgi Formu yetiştirme yurdunda kalan gençlerin sosyo-demografik özelliklerini, aile özelliklerini, eğitim durumunu, alışkanlıklarını belirlemek amaciyla literatürden yararlanarak hazırlandı $(11,15,19)$. Öğrenci Bilgi Formu 14 kapalı uçlu, 7 açık uçlu sorudan oluşturuldu. $\mathrm{Bu}$ form aracılığıyla elde edilen veriler araştırmada bağımsız değiş̧ken olarak kullanıldı.

\section{Ergen Problem Tarama Listesi}

Ergenlik dönemine özgü bedensel gelişim, toplumsal gelişim, karşı cinsle ilişki ve cinsel bilgiler, psikolojik gelişim ve gelecek beklentileri ile ilgili beş sorun alanını içeren alt bölümler ve toplam 55 maddeden oluşan Ergen Problem Tarama Listesi, 1993 yılında Tekelioğlu tarafından hazırlanmıştır (19). Bu anket formunun değerlendirme aşamasında "evet" cevabı verilen her soru için bir puan, "hayır" cevabı verilen her soru için sıfır puan verilerek her bir alt bölümün kümülatif toplamı elde edilmiş ve alt bölümlerin madde sayısına bölünerek alt bölümlerin puanları hesaplanmıştır. Puanı yüksek olan maddeler için sorun alanının fazla olduğu kabul edilmiştir.

\section{Ergenlerde Sorunlarla Başa Çıkma Ölçeği (ESBÇO)}

Patterson ve McCubbin tarafından geliştirilen ve Öngen (2002) tarafından Türkçe'ye çevrilen ve güvenilirliği yapılan ESBÇO likert tipi ölçek olup 54 maddeden oluşmaktadır $(15,30)$. Ölçekte yer alan maddeler " 0 = hiçbir zaman, 2 = ender olarak, 3 = ara sira, $4=$ sik sik, $5=$ her zaman" olmak üzere 5 'li dereceleme ölçeği ile cevaplandırılmaktadır. Ölçeğin çalışmada kullanımı konusunda Öngen'den izin alınmıştır.

Veri toplama araçlarının uygulanması için araştırma kapsamındaki kurumların idarecileriyle işbirliği yapılarak, gençler gruplar halinde sessiz bir ortama alınd, anket formları gözlem altında kendileri tarafından dolduruldu. Araştırmanın amacı ve anket formlarının nasıl doldurulacağına dair açıklama yapıldı. Araştırmadan elde edilen veriler bir istatistik programında değerlendirildi. Verilerin analizinde yüzdelik, ortalama, standart sapma, $\mathrm{t}$ testi, tek yönlü varyans analizi (ANOVA), Kruskal-Wallis testi, Scheffe testi, Mann-Whitney U testi ve korelasyon katsayısı kullanıldı. 


\section{BULGULAR}

Araştırmaya katılan ergenlerin sosyo-demografik özelliklerinin dağılımı Tablo 1'de verildi. Tablo incelendiğinde; araştırmaya katılan ergenlerin \% 51,7'sinin erkek, \% 69,0'unun 15-17 yaş grubunda olduğu, yaş ortalamalarının $16,13 \pm 1,47$ (min:12- max:19), kuruma ilk geliş yaş ortalamalarının 8,16 $\pm 4,36$ (min:0-max:16) yaş olduğu ve \% 51,8'inin 6-11 yaş grubunda kuruma geldikleri, ergenlerin \% 46,0'sının anne ve babasının her ikisinin de sağ olduğu, \% 54,7'sinin koruma altında kardeşi olduğu, koruma altında kardeşi olan ergenlerin yarısının (\% 51,2) kardeşi ile aynı yurtta olduğu görülmektedir.

Tablo 1. Ergenlerin Sosyo-Demografik ve Bazı Aile Özelliklerinin Dağılımı (n:87)

\begin{tabular}{|c|c|c|}
\hline SOSYO-DEMOGRAFİK ÖZELLİKLER & Say1 & $\%$ \\
\hline $\begin{array}{l}\text { Cinsiyet } \\
\mathrm{K}_{1 \mathrm{z}} \\
\text { Erkek }\end{array}$ & $\begin{array}{l}42 \\
45\end{array}$ & $\begin{array}{l}48,3 \\
51,7\end{array}$ \\
\hline $\begin{array}{l}\text { Yaş Grubu } \\
12-14 \text { yaş (erken ergenlik) } \\
15-17 \text { yaş (orta ergenlik) } \\
18-19 \text { yaş (geç ergenlik) } \\
\text { Yaş } \overline{\mathbf{X}}: 16.13 \pm 1.47 \text { (min:12-max:19) }\end{array}$ & $\begin{array}{l}11 \\
60 \\
16\end{array}$ & $\begin{array}{l}12,6 \\
69,0 \\
18,4\end{array}$ \\
\hline $\begin{array}{l}\text { Kuruma İlk Geliş Yaşı } \\
0-5 \text { yaş* } \\
\text { 6-11 yaş } \\
12 \text { yaş ve üstü } \\
\text { Kuruma Geliş Yaşı } \overline{\mathbf{X}}: 8.16 \pm 4.36 \text { (min: } 0 \text {-max:16) }\end{array}$ & $\begin{array}{l}21 \\
45 \\
21\end{array}$ & $\begin{array}{l}24,1 \\
51,8 \\
24,1\end{array}$ \\
\hline $\begin{array}{l}\text { Kronik Hastalik } \\
\text { Olan** } \\
\text { Olmayan }\end{array}$ & $\begin{array}{c}3 \\
84\end{array}$ & $\begin{array}{c}3,4 \\
96,6\end{array}$ \\
\hline $\begin{array}{l}\text { Öğrenim Durumu } \\
\text { İlköğretim öğrencisi } \\
\text { Lise öğrencisi } \\
\text { Meslek eğitimi alan } \\
\text { Okula gitmeyen*** }\end{array}$ & $\begin{array}{c}23 \\
56 \\
2 \\
6\end{array}$ & $\begin{array}{c}26,4 \\
64,4 \\
2,3 \\
6,9\end{array}$ \\
\hline $\begin{array}{l}\text { Anne ve Babanın Hayatta Olma Durumu } \\
\text { Her ikisi de sağ olan } \\
\text { Sadece annesi sağ olan } \\
\text { Sadece babası sağ olan } \\
\text { Her ikisi de ölmüş olan ya da durumunu bilmeyen }\end{array}$ & $\begin{array}{c}40 \\
29 \\
9 \\
9\end{array}$ & $\begin{array}{l}46,0 \\
33,4 \\
10,3 \\
10,3\end{array}$ \\
\hline $\begin{array}{l}\text { Koruma Altında Kardeşi Olma Durumu (n:75) } \\
\text { Olan } \\
\text { Olmayan }\end{array}$ & $\begin{array}{l}41 \\
34\end{array}$ & $\begin{array}{l}54.7 \\
45.3 \\
\end{array}$ \\
\hline $\begin{array}{l}\text { Kardeşi ile Aynı Yurtta Olma Durumu (n:41) } \\
\text { Olan } \\
\text { Olmayan }\end{array}$ & $\begin{array}{l}21 \\
20\end{array}$ & $\begin{array}{l}51.2 \\
48.8\end{array}$ \\
\hline $\begin{array}{l}\text { Algılanan Akademik Başarı (n:81) } \\
\text { Başarısız } \\
\text { Orta } \\
\text { İyi } \\
\text { Çok iyi }\end{array}$ & $\begin{array}{c}11 \\
31 \\
31 \\
8\end{array}$ & $\begin{array}{c}13,6 \\
38,3 \\
38,3 \\
9,9\end{array}$ \\
\hline Toplam & 87 & $\overline{100,0}$ \\
\hline
\end{tabular}

* Bu gruptakilerden 2 kişi doğduğundan beri, 1 kişi 2 aylık, 2 kişi 3 aylık ve bir kişi 10 aylık olduğundan beri kurumda kalmaktadır.

** Bu grupta kronik hastalığı olanlar; astım, bel ağrısı ve psikiyatrik bozukluğu olanlardır.

***Bu grupta okula gitmeyenlerden bir kişi lise öğrenimini tamamlamış ve üniversite sınavlarına hazırlanmaktadır. Diğerleri ise okulu bırakmışlardır. 
Öğrenim durumları incelendiğinde; yarıdan fazlasının $(\% 64,4)$ lise öğrencisi olduğu ve algilanan akademik başarıları sorgulandığında çoğunluğun $\quad(\% 38,3)$ akademik başarısını ne iyi ne de kötü olarak değerlendirdikleri görülmektedir. Araştırmaya katılan ergenlerin madde kullanma durumları Tablo 2'de verildi. Tablo incelendiğinde \% 44,8'inin şu ana kadar en az bir defa sigara içtiği, \% 34,5'inin sigara içmeye devam ettiği, içenlerin ise yarısının (\% 50,0) paket alıp günde en az 3 tane sigara içtiği, ayrıca ergenlerin \% 4,6’sının alkol kullandığı görülmektedir.

Tablo 2. Araştırmaya Katılan Ergenlerin Madde Kullanma Durumları (n:87)

\begin{tabular}{|c|c|c|}
\hline MADDE KULLANMA DURUMU & Say1 & $\%$ \\
\hline $\begin{array}{l}\text { Şimdiye Kadar Sigara İçme Durumu } \\
\text { İçen } \\
\text { İçmeyen }\end{array}$ & $\begin{array}{l}39 \\
48 \\
\end{array}$ & $\begin{array}{l}44,8 \\
55,2 \\
\end{array}$ \\
\hline $\begin{array}{l}\text { Halen Sigara İçme Durumu } \\
\text { İçen } \\
\text { İçmeyen }\end{array}$ & $\begin{array}{l}30 \\
57 \\
\end{array}$ & $\begin{array}{l}34,5 \\
65,5 \\
\end{array}$ \\
\hline $\begin{array}{l}\text { Sigara İçme S1klığ } 1 \text { (n:30) } \\
\text { İkram edildiğinde içen } \\
\text { Paket alıp günde } 1-3 \text { tane içen } \\
\text { Paket alıp günde } 3 \text { taneden fazla içen }\end{array}$ & $\begin{array}{c}6 \\
9 \\
15 \\
\end{array}$ & $\begin{array}{l}20,0 \\
30,0 \\
50,0 \\
\end{array}$ \\
\hline $\begin{array}{l}\text { Alkol Kullanma Durumu } \\
\text { Kullanan } \\
\text { Kullanmayan }\end{array}$ & $\begin{array}{c}4 \\
83\end{array}$ & $\begin{array}{c}4,6 \\
95,4\end{array}$ \\
\hline Toplam & 87 & $\overline{100,0}$ \\
\hline
\end{tabular}

Ergen Problem Tarama Listesi alt boyut ortalamaları Tablo 3'de verilmiştir. Tablo incelendiğinde en fazla sorun yaşanan alanın gelecekle ilgili düşünce ve istekler alt boyutunda olduğu ( $\overline{\mathbf{X}}: 0,51 \pm 0,23)$, bunu toplumsal gelişim problemleri alt boyutunun ( $\overline{\mathbf{X}}: 0,38 \pm 0,23$ ) takip ettiği, en az sorun yaşanan alanın ise karşı cinsle arkadaşlık ve cinsel bilgileri öğrenme olduğu ( $\overline{\mathbf{X}}: 0,23 \pm 0,22$ ) görülmektedir.

Tablo 3. Ergen Problem Tarama Listesi Alt Boyut Ortalamaları

\begin{tabular}{|l|l|l|l|}
\hline ALT BOYUTLAR & $\overline{\mathbf{X}} \pm \mathrm{SS}$ & $\begin{array}{l}\text { Minimu } \\
\mathrm{m}\end{array}$ & Maximum \\
\hline \hline Bedensel gelişim problemleri & $0.34 \pm 0.22$ & 0.00 & 0.90 \\
\hline Toplumsal gelişim problemleri & $0.38 \pm 0.23$ & 0.00 & 0.88 \\
\hline Karşı cinsle arkadaşlık ve cinsel bilgileri öğrenme & $0.23 \pm 0.22$ & 0.00 & 0.89 \\
\hline Psikolojik gelişim problemleri & $0.36 \pm 0.21$ & 0.00 & 1.00 \\
\hline Gelecekle ilgili düşünce ve istekler & $0.51 \pm 0.23$ & 0.00 & 0.89 \\
\hline
\end{tabular}


Tablo 4'de cinsiyete göre Ergen Problem Tarama Listesi alt boyut ortalamaları görülmektedir. Tabloda, karşı cinsle arkadaşlık ve cinsel bilgileri öğrenme alt boyutu puan ortalaması erkeklerde $(\overline{\mathbf{X}}: 0,30 \pm 0,24)$ kızlara ( $\overline{\mathbf{X}}: 0,15 \pm 0,18)$ göre daha yüksek olup, gruplar arasındaki fark istatistiksel olarak anlamlı bulundu (t: $3,287 ; \mathrm{p}<0,05)$.

Tablo 4. Cinsiyete Göre Ergen Problem Tarama Listesi Alt Boyut Ortalamaları

\begin{tabular}{|l|l|l|l|}
\hline ALT BOYUTLAR & $\begin{array}{l}\text { K1z (n:42) } \\
\overline{\mathbf{X}}_{ \pm \mathrm{SS}}\end{array}$ & $\begin{array}{l}\text { Erkek (n:45) } \\
\overline{\mathbf{X}}_{ \pm \mathrm{SS}}\end{array}$ & $\mathrm{t}$ ve $\mathrm{p}$ \\
\hline \hline Bedensel gelişim problemleri & $0,36 \pm 0,19$ & $0,31 \pm 0,24$ & $\begin{array}{l}\mathrm{t}: 1,070 \\
\mathrm{p}>0,05\end{array}$ \\
\hline Toplumsal gelişim problemleri & $0,39 \pm 0,22$ & $0,38 \pm 0,23$ & $\begin{array}{l}\mathrm{t}: 0,190 \\
\mathrm{p}>0,05\end{array}$ \\
\hline Karşı cinsle arkadaşlık ve cinsel bilgileri öğrenme & $0,15 \pm 0,18$ & $0,30 \pm 0,24$ & $\begin{array}{l}\mathrm{t}: 3,287 \\
\mathrm{p}<0,05\end{array}$ \\
\hline Psikolojik gelişim problemleri & $0,36 \pm 0,16$ & $0,36 \pm 0,25$ & $\begin{array}{l}\mathrm{t}: 0,080 \\
\mathrm{p}>0,05\end{array}$ \\
\hline Gelecekle ilgili düşünce ve istekler & $0,51 \pm 0,21$ & $0,52 \pm 0,25$ & $\begin{array}{l}\mathrm{t}: 0,202 \\
\mathrm{p}>0,05\end{array}$ \\
\hline
\end{tabular}

Anne ve babanın yaşama durumuna göre Ergen Problem Tarama Listesi alt boyut ortalamaları Tablo 5'de verildi. Tabloda görüldüğü gibi, karşı cinsle arkadaşlık ve cinsel bilgileri öğrenme boyutunda sadece babası yaşayanlarda $(\overline{\mathbf{X}}: 0,39 \pm 0,27)$ diğer gruplara göre daha fazla sorun yaşanmaktadır. Gruplar arasındaki fark istatistiksel olarak anlamlı bulundu $(\mathrm{KW}: 7,842, \mathrm{p}<0,05)$. Yapilan ileri analizde (Scheffe test) sadece babası sağ olan grupla anne babası yaşayan ve her ikisi de ölmüş olan grup arasında istatistiksel olarak farklılık olduğu $(\mathrm{p}<0,05)$ belirlendi. Toplumsal gelişim problemleri boyutunda yine sadece babası sağ olanlarda en fazla, her iki ebeveyni ölmüş olanlarda en az düzeyde sorun görülmesine karşın gruplar arasındaki fark istatistiksel olarak anlamlı bulunmadı $(\mathrm{p}>0,05)$.

Tablo 5. Anne ve Babanın Yaşama Durumuna Göre Ergen Problem Tarama Listesi Alt Boyut Ortalamaları

\begin{tabular}{|l|l|l|l|l|l|}
\hline ALT BOYUTLAR & $\begin{array}{l}\text { Her ikisi de } \\
\text { sağ (n:40) } \\
\overline{\mathbf{X}}_{ \pm} \mathrm{SS}\end{array}$ & $\begin{array}{l}\text { Sadece anne } \\
\text { sağ (n:29) } \\
\overline{\mathbf{X}}_{ \pm \mathrm{SS}}\end{array}$ & $\begin{array}{l}\text { Sadece baba } \\
\text { sağ (n:9) } \\
\overline{\mathbf{X}}_{ \pm \mathrm{SS}}\end{array}$ & $\begin{array}{l}\text { İkisi ölü ya da } \\
\text { bilmiyor (n:9) } \\
\overline{\mathbf{X}}_{ \pm} \mathrm{SS}\end{array}$ & KW ve P \\
\hline $\begin{array}{l}\text { Bedensel gelişim } \\
\text { problemleri }\end{array}$ & $0,34 \pm 0,26$ & $0,33 \pm 0,20$ & $0,31 \pm 0,13$ & $0,35 \pm 0,17$ & $\begin{array}{l}\mathrm{KW}: 0,183, \\
\mathrm{p}>0,05\end{array}$ \\
\hline $\begin{array}{l}\text { Toplumsal gelişim } \\
\text { problemleri }\end{array}$ & $0,39 \pm 0,23$ & $0,37 \pm 0,22$ & $0,44 \pm 0,21$ & $0,32 \pm 0,27$ & $\begin{array}{l}\mathrm{KW}: 1,266, \\
\mathrm{p}>0,05\end{array}$ \\
\hline $\begin{array}{l}\text { Karş1 cinsle arkadaşlik ve } \\
\text { cinsel bilgileri öğrenme }\end{array}$ & $0,18 \pm 0,19$ & $0,27 \pm 0,22$ & $0,39 \pm 0,27$ & $0,16 \pm 0,22$ & $\begin{array}{l}\mathrm{KW}: 7,842, \\
\mathrm{p}<0,05\end{array}$ \\
\hline $\begin{array}{l}\text { Psikolojik gelişim } \\
\text { problemleri }\end{array}$ & $0,36 \pm 0,20$ & $0,36 \pm 0,21$ & $0,37 \pm 0,10$ & $0,37 \pm 0,33$ & $\begin{array}{l}\mathrm{KW}: 0,774, \\
\mathrm{p}>0,05\end{array}$ \\
\hline $\begin{array}{l}\text { Gelecekle ilgili düşünce ve } \\
\text { istekler }\end{array}$ & $0,48 \pm 0,25$ & $0,52 \pm 0,23$ & $0,55 \pm 0,17$ & $0,55 \pm 0,27$ & $\begin{array}{l}\mathrm{KW}: 1,149, \\
\mathrm{p}>0,05\end{array}$ \\
\hline
\end{tabular}


Tablo 6'da Ergenlerde Sorunlarla Başa Çıkma Ölçeği alt boyut ortalamaları verilmiştir. Tabloda görüldüğü gibi kendini geliştirme ( $\overline{\mathbf{X}}: 3.55 \pm 0.82)$ en çok kullanılan başetme yöntemidir, bunu duygusal rahatlama $(\overline{\mathbf{X}}: 2.79 \pm 1.01)$ ve sorunu ciddiye almama/şaka yapma ( $\overline{\mathbf{X}}: 2.72 \pm 0.94$ ) takip etmektedir. Etkin olmayan yöntemlerden madde kullanma ( $\overline{\mathbf{X}}: 1.35 \pm 1.59$ ) başetmede en az kullanılan yöntemdir.

Tablo 6. Ergenlerde Sorunlarla Başa Çıkma Ölçeği Alt Boyut Ortalamaları

\begin{tabular}{|l|c|c|c|}
\hline ALT BOYUTLAR & $\overline{\mathbf{X}}_{ \pm \mathrm{SS}}$ & Minimum & Maximum \\
\hline \hline Sorunları aile ile çözme & $1.81 \pm 1.27$ & 0.00 & 5.00 \\
\hline Değişiklik arama & $2.68 \pm 0.79$ & 0.78 & 4.56 \\
\hline Olumsuz duyguları dişa vurma & $2.10 \pm 1.00$ & 0.00 & 5.00 \\
\hline Madde kullanma & $1.35 \pm 1.59$ & 0.00 & 5.00 \\
\hline Kendini geliştirme & $3.55 \pm 0.82$ & 1.43 & 5.00 \\
\hline Manevi destek arama & $2.69 \pm 1.13$ & 0.00 & 5.00 \\
\hline Psikolojik destek arama & $2.46 \pm 1.09$ & 0.00 & 5.00 \\
\hline Sorunu ciddiye almama/şaka yapma & $2.72 \pm 0.94$ & 0.60 & 4.80 \\
\hline Duygusal rahatlama & $2.79 \pm 1.01$ & 0.60 & 5.00 \\
\hline
\end{tabular}

Tablo 7'de cinsiyete göre Ergenlerde Sorunlarla Başa Çıkma Ölçeği alt boyut ortalamaları verildi. Tabloda görüldüğü gibi, erkeklerde olumsuz duyguları dışa vurma $\quad(\overline{\mathbf{X}}: 2.41 \pm 0.71), \quad$ madde kullanma $(\overline{\mathbf{X}}: 1,82 \pm 1,75) \quad$ ve manevi destek arama
( $\overline{\mathbf{X}}: 3,06 \pm 0,94$ ) yöntemleri başetmede kızlara göre daha fazla kullanılmaktadır ve gruplar arasındaki fark istatistiksel olarak anlamlıdır (Sirasıyla t:3,142, t:2,972, $\mathrm{t}: 3,368, \mathrm{p}<0,05)$.

Tablo 7. Cinsiyete Göre Ergenlerde Sorunlarla Başa Çıkma Ölçeği Alt Boyut Ortalamaları

\begin{tabular}{|l|c|c|c||}
\hline ALT BOYUTLAR & $\begin{array}{c}\text { Kız }(\mathrm{n}: 42) \\
\overline{\mathbf{X}}_{ \pm \mathrm{SS}}\end{array}$ & $\begin{array}{c}\text { Erkek }(\mathrm{n}: 45) \\
\overline{\mathbf{X}}_{ \pm \mathrm{SS}}\end{array}$ & $\mathrm{p}$ ve t \\
\hline \hline Sorunları aile ile çözme & $1,68 \pm 1,26$ & $1,94 \pm 1,29$ & $\mathrm{t}: 0,925, \mathrm{p}>0,05$ \\
\hline Değişiklik arama & $2,72 \pm, 0,71$ & $2,65 \pm 0,86$ & $\mathrm{t}: 0,412, \mathrm{p}>0,05$ \\
\hline Olumsuz duyguları dişa vurma & $1,77 \pm 1,80$ & $2,41 \pm 1,07$ & $\mathrm{t}: 3,142, \mathrm{p}<0,05$ \\
\hline Madde kullanma & $0,85 \pm 1,25$ & $1,82 \pm 1,75$ & $\mathrm{t}: 2,972, \mathrm{p}<0,05$ \\
\hline Kendini geliştirme & $3,58 \pm 0,81$ & $3,52 \pm 0,83$ & $\mathrm{t}: 0,345, \mathrm{p}>0,05$ \\
\hline Manevi destek arama & $2,29 \pm 1,18$ & $3,06 \pm 0,94$ & $\mathrm{t}: 3,368, \mathrm{p}<0,05$ \\
\hline Psikolojik destek arama & $2,37 \pm 0,87$ & $2,55 \pm 1,27$ & $\mathrm{t}: 0,766, \mathrm{p}>0,05$ \\
\hline Sorunu ciddiye almama/şaka yapma & $2,69 \pm 0,92$ & $2,76 \pm 0,96$ & $\mathrm{t}: 0,342, \mathrm{p}>0,05$ \\
\hline Duygusal rahatlama & $2,86 \pm 1,01$ & $2,73 \pm 1,01$ & $\mathrm{t}: 0,590, \mathrm{p}>0,05$ \\
\hline
\end{tabular}

Tablo 8'de anne ve babanın sağ olma durumuna göre ergenlerde sorunlarla başa çıkma ölçeği alt boyut ortalamaları gösterilmektedir. Anne ve babasının her ikisi de ölü olan ya da durumlarını bilmeyenlerin madde kullanma alt boyutu puan ortalamasının ( $\overline{\mathbf{X}}: 2,66 \pm 1,80)$ diğerlerine göre daha yüksek olduğu görülmektedir. Gruplar arasındaki fark istatistiksel olarak anlamlıdır (KW:10,436, p<0,05). 
Tablo 8. Anne ve Babanın Sağ Olma Durumuna Göre Ergenlerde Sorunlarla Başa Çıkma Ölçeği Alt Boyut Ortalamaları

\begin{tabular}{|c|c|c|c|c|c|}
\hline ALT BOYUTLAR & $\begin{array}{c}\text { Her ikisi de sağ } \\
\text { (n:40) } \\
\overline{\mathbf{X}}_{ \pm \mathrm{SS}}\end{array}$ & $\begin{array}{c}\text { Sadece anne sağ } \\
\text { (n:29) } \\
\overline{\mathbf{X}}_{ \pm \mathrm{SS}}\end{array}$ & $\begin{array}{c}\text { Sadece baba sağ } \\
\text { (n:9) } \\
\overline{\mathbf{X}}_{ \pm \mathrm{SS}}\end{array}$ & $\begin{array}{c}\text { İkisi ölü ya da } \\
\text { bilmiyor (n:9) } \\
\overline{\mathbf{X}}_{ \pm \mathrm{SS}}\end{array}$ & KW ve $p$ \\
\hline $\begin{array}{l}\text { Sorunları aile ile } \\
\text { çözme }\end{array}$ & $1,51 \pm 1,18$ & $2,11 \pm 1,22$ & $2,66 \pm 1,44$ & $1,37 \pm 1,27$ & $\begin{array}{c}\mathrm{KW}: 7,738, \\
\mathrm{p}>0,05\end{array}$ \\
\hline Değişiklik arama & $2,63 \pm 0,79$ & $2,62 \pm 0,72$ & $3,03 \pm 0,92$ & $2,72 \pm 0,90$ & $\begin{array}{c}\mathrm{KW}: 0,797 \\
\mathrm{p}>0,05\end{array}$ \\
\hline $\begin{array}{l}\text { Olumsuz duyguları } \\
\text { dişa vurma }\end{array}$ & $1,92 \pm 0,95$ & $2,24 \pm 0,92$ & $2,24 \pm 1,27$ & $2,35 \pm 1,16$ & $\begin{array}{c}\mathrm{KW}: 2,253 \\
\mathrm{p}>0,05\end{array}$ \\
\hline Madde kullanma & $0,85 \pm 1,28$ & $1,50 \pm 1,65$ & $1,83 \pm 1,71$ & $2,66 \pm 1,80$ & $\begin{array}{c}\mathrm{KW}: 10,436, \\
\mathrm{p}<0,05\end{array}$ \\
\hline Kendini geliştirme & $3,70 \pm 0,82$ & $3,52 \pm 0,71$ & $3,33 \pm 0,69$ & $3,19 \pm 1,16$ & $\begin{array}{c}\mathrm{KW}: 4,061 \\
\mathrm{p}>0,05\end{array}$ \\
\hline Manevi destek arama & $2,53 \pm 1,17$ & $2,62 \pm 1,10$ & $3,37 \pm 0,93$ & $2,96 \pm 1,07$ & $\begin{array}{c}\mathrm{KW}: 4,513, \\
\mathrm{p}>0,05\end{array}$ \\
\hline $\begin{array}{l}\text { Psikolojik destek } \\
\text { arama }\end{array}$ & $2,36 \pm 1,16$ & $2,53 \pm 0,93$ & $2,86 \pm 1,50$ & $2,30 \pm 0,80$ & $\begin{array}{c}\mathrm{KW}: 1,768 \\
\mathrm{p}>0,05\end{array}$ \\
\hline $\begin{array}{l}\text { Sorunu ciddiye } \\
\text { almama/şaka yapma }\end{array}$ & $2,65 \pm 0,90$ & $2,73 \pm 0,97$ & $2,95 \pm 0,94$ & $2,82 \pm 1,10$ & $\begin{array}{c}\mathrm{KW}: 1,111 \\
\mathrm{p}>0,05\end{array}$ \\
\hline Duygusal rahatlama & $2,86 \pm 1,06$ & $2,60 \pm 0,77$ & $3,37 \pm 1,09$ & $2,51 \pm 1,24$ & $\begin{array}{c}\mathrm{KW}: 3,662 \\
\mathrm{p}>0,05\end{array}$ \\
\hline
\end{tabular}

\section{TARTIŞMA}

Araştırmaya katılan ergenlerin çoğunluğunun başka çalışmalara $(19,31)$ benzer olarak kuruma ilk geliş yaş ortalamalarının 6-11 yaşları arasında olduğu belirlendi. Ülkemizde ilköğretim çağına denk gelen bu dönemde, kuruma yerleştirilme gibi büyük bir değişiklik ergenin uyum kapasitesini zorlayabilir. $\mathrm{Bu}$ ergenlerin eski yaşantılarına ait özelliklerin sürdürülmesi, hem yeni durumlarına uyumlarını kolaylaştırabilir hem de kendilerini yalnız, güçsüz ve umutsuz hissetmelerini engelleyebilir. Öngen (2002) in çalışmasında ergenlerin baş etme davranışlarının başında sorunları aile ile çözme geldiği tespit edilmiştir. Bu durumda, koruma altında kardeşi olan ergenlerin aynı yurtta kalmaları, problemlerle başetmede kardeşlerin birbirine destek olmaları açısından önemli görülmektedir (15).

Araştırmaya katılan ergenlerin önemli bir bölümünün sigara içtiği belirlendi (Tablo 2). Bedir (1998)'in çalışmasında; yetiştirme yurdunda kalan ergenlerin \% 23,4'ünün sigara içtiği saptanmıştır (32). Ülkemizdeki ergenlerle yapılan bir çalışmada, ergenlerin \% 15,5'inin sigara içmeyi birkaç kez denediği ve \% 17,0'sinin sigara içmeye devam ettiği bulunmuştur (33). Araştırma sonucunda elde edilen bulgunun literatürden belirgin oranda yüksek olduğu görülmüştür. $\mathrm{Bu}$ bulgu araştırma grubundaki ergenlerin daha çok 15-17 yaş grubunda olmasından kaynaklanabileceği gibi yetiştirme yurdundaki akranların birbirini etkilemesinden de ileri gelebilir. Madde bağımlılı̆̆ının ilk basamağını oluşturan sigara bağımlılığı etkin olmayan bir başetme yöntemidir. Araştırmaya katılan ergenlerde, sigara kullanımının bu denli yüksek olması, yetiştirme yurdunda yaşayan ergenlerde gelecekte sigaraya bağlı ortaya çıkabilecek akut ve kronik hastalıklar açısından risk oluşturmaktadır $(34,35)$.

Ergenlerin en fazla sorun yaşadığı alanın gelecekle ilgili düşünce ve istekler alt boyutunda olduğu görülmektedir. Yapılan birçok araştırmada benzer olarak ergenlerin aileden yoksun olma, gelecekte ne yapacağını bilememe ve iyi bir iş sahibi olamayacağ endişesine sahip oldukları gösterilmiştir $(11,27,31$, 36). Yetiştirme yurdunda kalan ergenlerin geleceğe 
yönelik yaşadıkları problemlerin kurum bakımından çıkarıldıktan sonraki hayatlarına ilişkin belirsizliklerden kaynaklanabileceği düşünülmektedir. Araştırmaya katılan ergenlerin, karşı cinsle arkadaşlık ve cinsel bilgileri öğrenme alt boyutu puan ortalaması erkeklerde kızlara göre daha yüksek olup, gruplar arasındaki fark istatistiksel olarak anlamlı bulunmuştur. TÜBA (2004) tarafından ülkemizdeki ergenler ile ilgili yapılan bir çalışmada karşı cinsten özel arkadaşı olan ergenlerin cinsiyete göre dağılımlarına bakıldığında erkeklerde özel arkadaşa sahip olma kızlara göre daha fazladır (33). Araştırmada bu bulgunun aksine erkek ergenlerde karşı cinsle arkadaşlık ve cinsel bilgileri öğrenme probleminin daha fazla yaşanması kurumların karışık değil, tek cinsiyete özgü olması sonucu kızlarla nasıl iletişimin kurulacağı konusundaki sosyal becerilerin yetersizliği ile açıklanabileceği gibi, kurumda bulunmaktan dolayı erkek ergenlerin kendilerine güvenmemeleri ve karşı cinsten olumsuz tepki almaktan korkmaları ile de açıklanabilir. Ayrıca kurumda özel konuların danışılabileceği uzmanların olmaması ve/veya karşı cinsle arkadaşlığın ve cinsel konuların ayıp ve mahrem sayılması ergenlerin bu probleme yönelik yardım almasını engelleyebilir.

Anne ve babanın yaşama durumuna göre karşı cinsle arkadaşlık ve cinsel bilgileri öğrenme boyutunda sadece babası yaşayanlarda diğer gruplara göre daha fazla sorun yaşanmaktadır. Gruplar arasındaki fark istatistiksel olarak anlamlı bulunmuştur. Bu durumun toplumumuzda baba ve çocuk-ergen arasındaki iletişimin mesafeli olması, baba ile kı-erkek arkadaşlığ1 ve cinsellik gibi konuların konuşulmasının ayıp sayılmasından kaynaklandığı düşünüldü.

Yetiştirme yurdunda kalan ergenlerde Sorunlarla Başa Çıkma Ölçeği alt boyut ortalamaları incelendiğinde, kendini geliştirme en çok kullanılan başetme yöntemidir, bunu duygusal rahatlama ve sorunu ciddiye almama/şaka yapma takip etmektedir. Etkin olmayan yöntemlerden madde kullanma başetmede en az kullanılan yöntemdir. Öngen'in (2002) ergenlerin başetme davranışlarını belirlemek için yaptığı çalışma sonucunda ergenlerin sorunlarla başetme davranışlarının başında sorunları aile ile çözme geldiğini, bunu değişiklik arama, olumsuz duyguları dışa vurma ve madde kullanmanın izlediği ortaya çıkmıştır. Hutchinson ve Tess'in (1992) kurum bakımında olan ergenler ile yaptığı çalışmada, madde kullanımının fazla olduğu tespit edilmiştir. Yetiştirme yurdunda kalan ergenlerin başetmede sorunları aile ile çözme yöntemini daha az kullanmaları aileden uzakta olmaları ve aileleriyle sadece ziyaret ettiklerinde ve izinli olduklarında bir araya gelmeleri nedeniyle olabilir. Araştırmaya katılan ergenlerin cinsiyetlerine göre Ergenlerde Sorunlarla Başa Çıkma Ölçeği alt boyut ortalamalarında erkekler olumsuz duyguları dışa vurma, madde kullanma ve manevi destek arama yöntemlerini kızlara göre daha fazla kullanmaktadır. Stresli durumlarda erkeklerin olumsuz duyguları daha çok dişa vurmaları kabul gören bir davranış iken aynı anlayış kızlara karşı gösterilmemektedir. Yani erkeklerin bu davranışı öğrenilmiş bir savunma yöntemidir. Madde kullanımı da (özellikle sigara) toplumumuzda erkek olmanın göstergelerinden sayılır. Stresli durumlarda erkeklerin sigara veya alkol kullanmaları doğal karşılanmaktadır. Bu iki etkin olmayan başetme yöntemini yetişkinlerde gören ergenlerin, rol modeli almaları doğaldır. Manevi destek arama bir din adamıyla konuşma, camiye gitme ve dua etmeyi içeren problem karşısında ortaya çıkan hoşa gitmeyen duyguların yönetimine yardımcı olan, kişiye problemin çözümü için etkin yöntemleri kullanana kadar zaman kazandıran duyguya yönelik başetme yöntemlerindendir (15, 38, 39). Öngen'in (2002) çalışmasında erkeklerin rahatlatıcı bir etkinlikte bulunma, madde kullanma ve plan yapma stratejilerini daha fazla kullandığg1, kızların ise kendini yenileme, duygusal rahatlama ve psikolojik destek arama yöntemlerinden daha fazla yararlandıkları bulunmuştur (15). Aydın’ın (2003) çalışmasında stresle başa çıkma tarzları ile cinsiyet arasındaki ilişkiye bakılmış ve 
kızların kendine güvenli yaklaşım, iyimser yaklaşım ve sosyal destek arama yaklaşımını erkeklere göre daha fazla tercih ettikleri belirlenmiştir (34). Bu sonuçlar araştırmamızla uyumlu bulunmuştur.

Yapılan çalışmada, anne ve babasının her ikisi de ölü olan ya da durumlarını bilmeyenlerin madde kullanma alt boyutu puan ortalamasının diğerlerine göre daha yüksek olduğu belirlenmiştir. Öngen'in (2002) ergenlerin başetme davranışlarını belirlemek için yaptığı çalışma sonucunda ergenlerin sorunlarla başetme davranışlarının başında sorunları aile ile çözme geldiğini, bunu değişiklik arama, olumsuz duyguları dişa vurma ve madde kullanmanın izlediğini ortaya koymuştur. Hutchinson ve Tess'in (1992) kurum bakımında olan ergenler ile yaptığı çalışmada, madde kullanımının fazla olduğu tespit edilmiştir (37). Yapılan araştırma da aile ile sorunlarını çözemeyen ergenlerin madde kullandıklarını göstermiştir.

Yetiştirme yurdunda kalan gençlerin ergenlik sorunları ve baş etmeleri konulu araştırmanın sonuçlarına göre; araştırmaya katılan ergenlerin sigara kullanma bulgularının literatüre göre yüksek olduğu ve özellikle erkeklerde, okula devam etmeyenlerde, annesi ve babasının her ikisi de ölü olan ya da durumunu bilmeyenlerde sorunlarla baş etmede madde kullanımına başvurulduğundan, bu gruplara madde kullanımı ve bırakma yöntemleri ile ilgili danışmanlık verilmesi ve etkin başetme yöntemlerini geliştirmeleri yönünde desteklenmeleri, sigara içen ergenlerin sigarayı bırakma, hiç başlamamış olanların madde bağımlılığı konusunda eğitilmesi önerilebilir.

Yetiştirme yurdunda kalan erkek ergenlerin karşı cinsle arkadaşlık ve cinsel bilgiler edinme alanında sorun yaşadıkları tespit edildiğinden bu konularda eğitilmeleri ve ergenlere yönelik karşı cinsle iletişim konusunda danışmanlık yapılabilir.

Yetiştirme yurdunda kalan erkeklerde sorunlarla başetmede olumsuz duyguları dışa vurma ve manevi destek arama yöntemleri kızlara göre daha fazla kullanıldığı tespit edildiğinden, erkeklere öfke kontrolü, madde ve kişilerarası ilişkiler konusunda danışmanlık verilmesi önerilebilir.

Kurumlarda çalışan hemşirelerin, kurumdaki ergenlerin yaşadıkları sorunlar doğrultusunda Kurumlarda hemşire istihdamının sağlanması ve çalışan hemşirelerin ergenlik problemleri konusunda yetiştirme yurdunda kalan ergenleri düzenli olarak takip etmesi ve bilgilendirmesi ve yetiştirme yurdunda çalışan hemşirelerin uygulamalarına rehberlik edecek çalışmaların yapılması önerilebilir.

Yetiştirme yurdunda kalan ergenlerin en fazla etkin yöntemlerden kendini geliştirmeyi kullanmaları olumlu bir sonuç olarak değerlendirilmelidir.

\section{KAYNAKLAR}

1. WHO The health of young people: A challenge and a promise, Geneva, 1993.

http://apps.who.int/iris/handle/10665/37353. Erişim Tarihi: 20.04.2014.

2. UNFPA State of World Population, 2005. http://www.unfpa.org/swp/2005/english/ch1/ Erişim Tarihi:20.04.2014.

3. DİE Genel Nüfus Sayımı 2000. http://tuikapp.tuik.gov.tr/nufusmenuapp/menu.zul. Erişim Tarihi:20.04.2014.

4. Geçtan E. Psikanaliz ve Sonrası. İstanbul, Hür Yayınlar1, 1981.

5. Dönmez A. Ergenliği Anlamak. Onur, B. Birinci Bask1, Ankara: İmge Kitabevi, 1995: 13-48.

6. Bulut I, Özdemir U. Yetiştirme Yurtları ve Gençlik Liderliği. Sosyal Hizmetler Dergisi. 1998; 1(7): 2025.

7. Temel ZF, Aksoy AB. Ergen ve Gelişimi. Birinci Bask1, Ankara: Nobel, 2001: 148 (1-11).

8. Yavuzer H. Çocuk Psikolojisi. Yirminci Baskı, İstanbul: Remzi Kitapevi, 2001: 264-88. 
9. Abalı O. Ergenlik Dönemi ve Sorunları. Birinci Bask1, İstanbul: Epsilon, 2004: 17-20.

10. Yörükoğlu A. Gençlik Çağı. 12. Baskı, İstanbul: Özgür Yayınları, 2004: 13-203.

11. Tuzcuoğlu AS. Korunmaya Muhtaç Çocukların Ergenlik Problemleri. Yüksek Lisans Tezi, Gazi Üniversitesi, Ankara: 1989.

12. Seifert KL, Hoffnung RJ, Child and Adolescent Development. Second Edition, USA, Houghton Mifflin Company, 1991: 505-606.

13. SHÇEK İstatistikleri 2005. http://www.shcek.gov.tr/portal/dosyalar/coc_hak/b m_ulke_raporu.asp. Erişim tarihi: 01.08.06.

14. Lazarus RS. Emotion and Adaptation. USA: Oxford Universty Pres, 1991: 112-13.

15. Öngen D. Ergenlerde Sorunlarla Başa Çıkma Davranışları. Eğitim ve Bilim. 2002; 27(125): 5461.

16. Punar H. 16-18 Yaş Grubu Korunmaya Muhtaç Çocukların Kaygı ve Uyum Düzeyleri. Yüksek Lisans Tezi, Ankara Üniversitesi, Ankara: 1988: 75-78.

17. Cılga İ. Korunmaya Muhtaç Gençlerin Sorunları ve Yetiştirme Yurtları. T.C. Başbakanlık Gençlik ve Spor Genel Müdürlüğü Gençlik Hizmetleri Daire Başkanlığı, Ankara: 1989: 62-68.

18. Washington G. 10-12 Yaş Grubu Korunmaya Muhtaç Yuva Çocuklarında Denetim Odağı Algısı ve Kendine Saygı Duygusu. Yüksek Lisans Tezi, Ankara Üniversitesi, Ankara: 1989.

19. Tekelioğlu FY. Yetiştirme Yurdunda Yaşayan 1317 Yaş Grubu Okuyan Gençler ile Aileleri Yanında Yaşayan ve Okuyan Aynı Yaş Grubu Gençlerin Ergenlik Problemlerinin Karşılaştırılması. Yüksek Lisans Tezi, Marmara Üniversitesi, İstanbul: 1993.
20. Altay S, Arancioğlu, A, Bal C, Cihan H, Demir D, Demirat F. Yetiştirme Yurtlarında Kalan 15-17 Yaş Korunmaya Muhtaç Çocukların Sosyo-Demografik Özellikleri ve Gelişimleri. Lisans Tezi, Hacettepe Üniversitesi, Ankara: 1994.

21. Aslan Z, Bayır İ, Berber Ö, Çelen Ü, Gültekin MÖ, Kurşunoğlu Ö. Yetiştirme Yurdunda ve Ailesi Yanında Kalan 14-19 Yaş Grubundaki Öğrencilerin Kayg1 Düzeyleri. Lisans Tezi, Hacettepe Üniversitesi, Ankara: 1994.

22. Özdaş Y. Yetiştirme Yurdundan Ayrılan Kız Çocuklarının Toplumsal Uyumuna İlişkin Bir Araştırma-Van Örneği. Yüksek Lisans Tezi, Yüzüncü Y1l Üniversitesi, Van: 1996.

23. Yaşar F. Elazığ ve Malatya İllerindeki Çocuk Yuvası ve Yetiştirme Yurtlarında Kalan Korunmaya Muhtaç Çocukların Fiziksel ve PsikoSosyal Sorunlarının Araştırılması. Uzmanlık Tezi, Fırat Üniversitesi, Elâzı ğ: 1996.

24. Aslan B. Kurum Bakımında Bulunan Korunmaya Muhtaç Çocukların Davranış Sorunları-Adana İlinde Bir Araştırma. Yüksek Lisans Tezi, Hacettepe Üniversitesi, Ankara: 1997.

25. Erim B. Yetiştirme Yurtlarında ve Aileleri Yanında Yaşayan Ergenlerin, Benlik Saygısı, Depresyon ve Yalnızlık Düzeyleri ile Sosyal Destek Sistemleri Açısından Karşılaştırılması. Yüksek Lisans Tezi, Ankara Üniversitesi, Ankara: 2001.

26. Gürvardar D. Yetiştirme Yurdunda Yetişen Çocuklar ile Ana-Baba Yanında Yetişen Çocukların Umutsuzluk Düzeyinin Karşılaştırılması. Yüksek Lisans Tezi, Dokuz Eylül Üniversitesi, İzmir: 2001.

27. Uras B. Kurum Bakımında Olan ve Ailesi Yanında Kalan Çocuklarda Öğrenilmiş Çaresizlik ile Depresyon Puanları Arasındaki İlişkinin İncelenmesi. Yüksek Lisans Tezi, Ege Üniversitesi, İzmir, 2001. 
28. Gürbüz EE. Kurumda Yaşayan Korunmaya Muhtaç Çocuklarda Rorschach Testinin Kendilik Algısı Duygulanım ve Fikir Yürütme Boyutlarının İncelenmesi. Yüksek Lisans Tezi, İstanbul Üniversitesi, İstanbul: 2002.

29. Reçber B. Bir Özsaygı Geliştirme Programının Yetiştirme Yurdunda Yaşayan Ergenlerin Özsaygı Düzeyleri Üzerinde Etkililiği. Yüksek Lisans Tezi, Uludağ Üniversitesi, Bursa: 2002.

30. Patterson JM, McCubbin H, Adolescet Coping Style and Behaviors: Conceptualization and Measurement. Journal of Adolescence. 1987; 10(2): $163-86$ http://dx.doi.org/10.1016/S0140-1971(87)80086-6

31. Çetin H. Yetiştirme Yurtlarındaki Adölesanların Benlik Saygıları ve Psikolojik Belirtileri. Doktora Tezi, Ankara: 2004.

32. Bedir E. Denizli İli 12-18 Yaş Yetiştirme Yurdu Çocuklarının Fiziksel ve Ruhsal Durumlarının Değerlendirilmesi. Uzmanlık Tezi, Denizli: 1998.

33. TÜBA-UNFPA Nüfus ve Kalkınma Stratejileri Alt Programı. Türkiye Bilimsel Akadamesi Raporları Sayı 4. 2004.
34. Nicolson D, Ayers H. Adolescent Problems. British: David Fulton Publishers Ltd, 2004;4-7.

35. Konopka G. Coping with Stresses and Strains of Adolescence. Social Development, 1980, 4: 1-17. Aktaran: Öngen, D. Ergenlerde Sorunlarla Başa Çıkma Davranışları. Eğitim ve Bilim. 2002; 27(125): 54-61.

36. Yigit, H. Alt ve üst sosyo-ekonomik düzey ve cinsiyet açısından ergenlik dönemi problemlerinin karşılaştırılması. Yüksek Lisans Tezi, Ankara, 2001.

37. Hutchinson RL, Tess DE. Psychosocial characteristics of institutionalized adolescents: resilient or at risk. Adolescence, 1992, 27(106).

38. Aydın AS. Ergenlerde Stresle Başaçıkma Tarzları ile Cinsiyet ve Cinsiyet Rolleri Arasındaki İlişki. Yüksek Lisans Tezi, İstanbul: 2003.

39. Baltaş A, Baltaş Z. Stres ve Başaçıkma Yolları. 21. Bask1. Remzi Kitabevi, Ankara: 2002; 122-124. 